\title{
A Study Of Customer Interface In E-Banking In China
}

Zheng Wang, (E-mail: zheng408@gmail.com), Pace University James Lawler, (Email: jlawler@pace.edu), Pace University

\begin{abstract}
With the accession of China to the World Trade Organization (WTO), banking in the country is anticipated to be fully liberalized by 2007. Banks in China are accordingly reforming their businesses, in order to address challenges from foreign banks and to compete effectively in a liberalized economy. Banking on the Internet is frequently considered by the financial industry as a critical differential in a global economy. This study explores Web sites of key Chinese banks on building blocks of e-Banking customer interface, consisting of context, content, communication, connection, community, customization and commerce, and evaluates the readiness of China for $21^{\text {st }}$ century competitive e-Banking. The study contributes insight that can benefit business directors in banks in China in attempting to improve their e-Banking strategy in the growing global market.
\end{abstract}

\section{BACKGROUND}

7 anks globally consider the Internet as an emerging business channel, connecting current and future customers in a critical media. Banking on the Internet has been demonstrated as an effective method to enter a financial market, especially a foreign market. Studies have highlighted Citibank entering the Japanese market with an e-Banking solution on the World Wide Web (Siaw \& Yu, 2004). The Royal Bank of Canada has entered the market in the United States by acquiring the all-virtual Web-based Security First Network Bank (SFNB), and the Canada Imperial Bank of Commerce has entered the market with combined channels of e-Banking and supermarket-based Automated Teller Machines (ATM). Competition globally among banks is increasing in the paradigm of the Web.

Since the introduction of Web-based Security First Network Bank (SFNB) in 1995, the number of virtual banks has increased internationally, as traditional banks have included e-Banking in their businesses. Studies, such as the On-Line Banking Report: The True US Internet Banks, have indicated more than 200 new Web-based banks from traditional banks in the United States in 1999 (Siaw \& Yu, 2004). By the conclusion of 2002, 120 of the biggest banks in the United States had initiated e-Banking functionality (Pikkarainen, et .al., 2004 \& Pyun et. al., 2002). Though cost benefits have been a consideration in e-Banking growth, customer relationship management (CRM) has developed as a frequent consideration in the design of e-Banking businesses. Customer relationship management is defined in this study as a strategy of optimizing the processes of financial service businesses, which enable the marketing, sales and service of products, though innovation of integrated customer channels, including that of the functionality of the Web, and which enable customer loyalty and financial service profitability.

Studies in the literature have focused on efforts to develop customer relationship management in e-Banking. Relationship marketing is indicated to enable a customer equity-building strategy, in acquiring, retaining and selling further services to desired customers, by taking advantage of e-Banking (Sarel \& Marmorstein, 2003). Bankers know that retention and satisfaction of customers is critical in e-Banking. Establishing continued relationship is important in establishing customer benefits on the Web. Sites are evolving from basic information offering to complex service sites (Bauer, et. al., 2004). With the latter sites, bankers may deliver personalized product information tailored to best customers. The field is changing from competing by brand or product to tailoring products to profitable customers in optimal customer relationships (Siaw \& Yu, 2004).

Banks have introduced features of relationship management on to their Web sites, which are evolving fast 
into on-line portal services. Customer penetration and satisfaction are increasing as a result. Surveys from Forbes indicate satisfaction in the banking industry (Orr, 2004), as in non-banking industries. The acceptance of e-Banking on the Web has been increasing internationally, not only in countries considered leaders in the services, but in non-leaders (Pikkarainen, et. al., 2004).

In this exploratory paper, the evolution in customer relationship management, and the growth of e-Banking as important in services, furnishes a frame of reference to introduce a study of e-Banking in China. Few papers have extended the international literature to study Chinese e-Banking on the Web. The intent of the study is to furnish insight into the functionality of Chinese e-Banking Web sites, as China competes further in the global financial market of services.

\section{INTRODUCTION}

The dimensions of banking in China furnish increased opportunities for bankers. Studies indicate that banking in China had approximated $\$ 3,335.2$ billion in 2003, accounting for $23.1 \%$ in assets of the Asia-Pacific banking industry (Datamonitor, 2004). Banking in China is forecasted to be $\$ 6,102.6$ billion in 2008, an increase of 83.0\% from 2003 (Datamonitor, 2004), as indicated in Figure 1. With the accession of China to the World Trade Organization (WTO), banking in China is anticipated to be effectively and fully liberalized by 2007.

Figure 1: Banking Industry in China (Dollars in Billions)

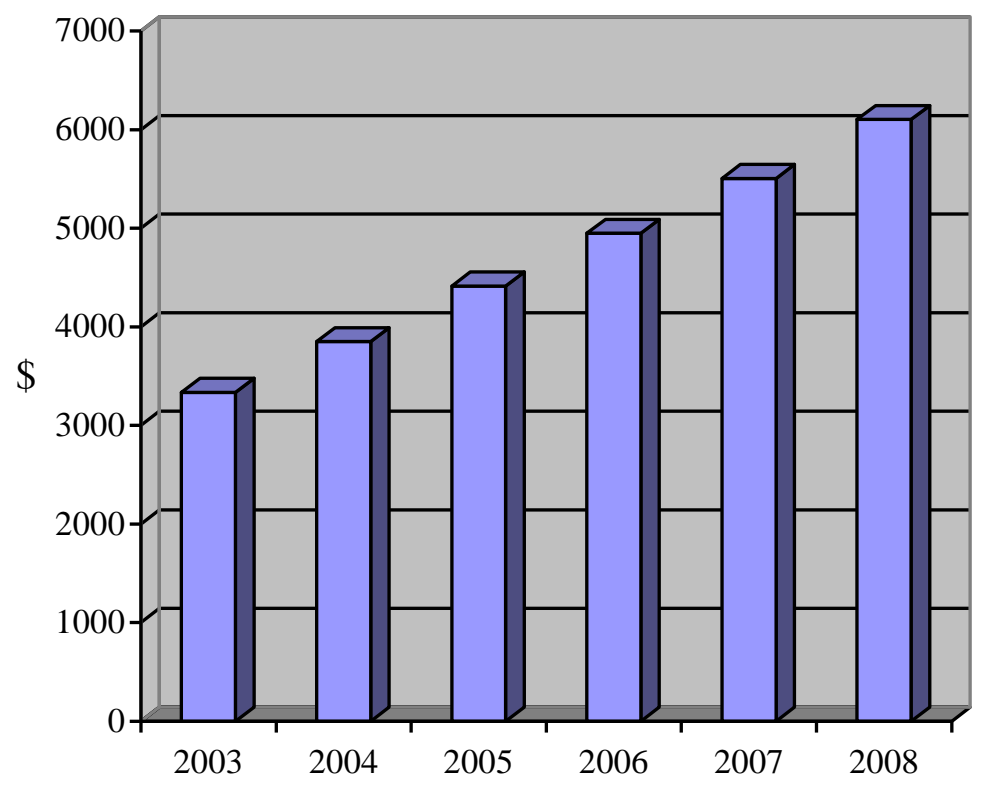

(Source: Datamonitor: Banks in China - Industry Profile, 2004 [Adapted])

Development of the computer infrastructure and of client consumers on the Web is contributing to a firm foundation for e-Banking in China. Studies indicate computers in China are doubling each 28 months and are anticipated to exceed the number of computers in the United States. Cell phones of 300 million already exceed those in the United States (Ashling, 2005). China is already internationally the second largest market on the Web (Wong, et. al., 2004). Number of client consumers in China on the Web is 103 million, of which 53 million has broadband services, such as cable and DSL, 29.7 million LANs, and 5.5 million ISDN (China Internet Network Information 
Center [CNNIC], 2005), as indicated in Figure 2.

Further research studies (Sarel \& Marmorstein, 2003, Pikkarainen, et. al., 2004, and Barbesino, et. al., 2005) however indicate that development on the Web in other countries is considered more advanced than China, as in Europe or North America, such as in the United States. Focus on China, considered to be a country in development, is limited in the studies. Insight from studies of non-Asian countries may not be helpful in a study of China on the Web, considering articulated cultural distance between the East and the West. Special studies (Laforet and Li, 2005) of China indicate that clients of e-Banking in this country are distinct in demographic and cultural considerations, which entice further review of Chinese e-Banking and the inclusion of its already advanced infrastructure of technology on the Web.

Figure 2: Clients of Chinese Web

(Client Consumers in Millions)

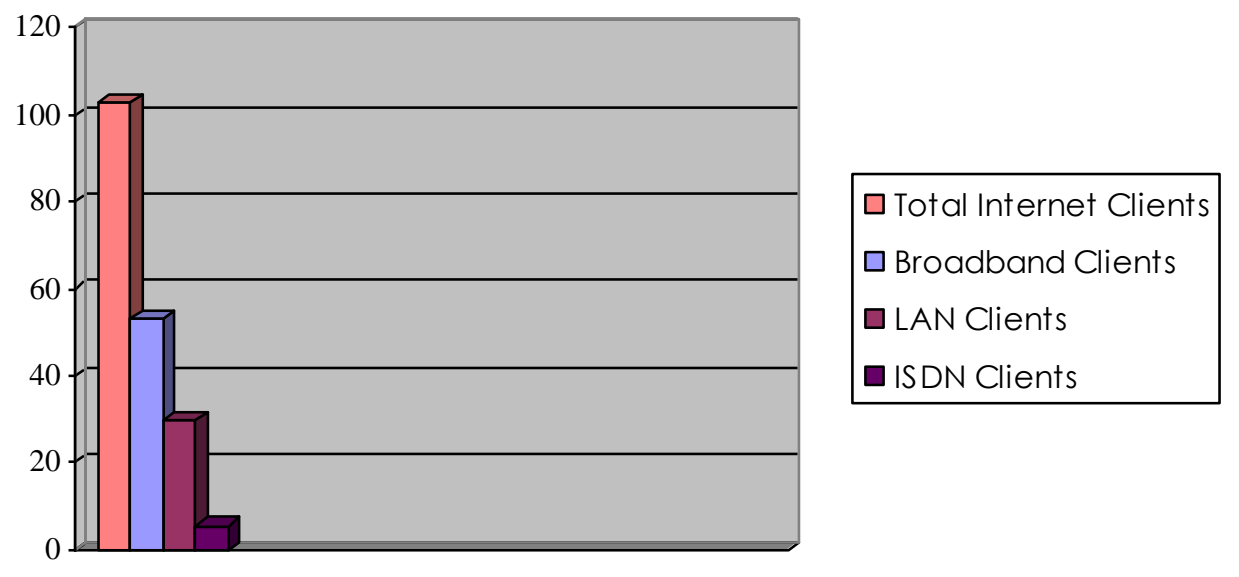

(Source: China Internet Network Information Center, CNNIC, 2005)

Chinese e-Banking began in 1997. China Merchants Bank (CMB) is first in launching an Internet payment system in China, in "All in One Net." More than $40 \%$ of the business of this bank is done by customers on the Web (Asia Pulse, 2001). Industrial and Commercial Bank of China (ICBC) furnishes e-Banking in 300 cities of China for $\$ 25$ billion (Asia Pulse, 2001) and is considered internationally as a "best on-line bank", which is the first honor granted a financial institution in a developing economy (Lu, et. al., 2005). From 2002 eight large-sized and medium-sized banks, which comprise half of the banks in China, have been approved by the government to initiate e-Banking on the Web (Lu, et. al., 2005). Chinese e-Banking continues however to be low. Studies indicate consumers in China access the Web for entertainment and information, not financing. Accessing is for e-mailing and searching on the Web, and less for e-Banking. Chinese consumers do not consider e-Banking a core activity, and the impact of banking on the Web is therefore low.

Laforet and $\mathrm{Li}$ (2005) indicate that the current market for e-Banking in China nationally is relatively small, though larger in urban centers of the country, where 33\% of consumers are e-Banking customers, and technology is concentrated in the centers. Their findings indicate that the potential of a middle class urban market ought not to be underestimated by bankers. These studies introduce a lack of influence from the bankers, which is contributing limited information on e-Banking in general and low e-Banking of consumers as bona fide customers. Low confidence in personal financial management on the Web and perceived risk of fraud on the World Wide Web are concurrently contributing to low e-Banking. Low relationship management on the Web is further impacting low e-Banking in China. Laforet and Li nevertheless indicate a diminishment of the aforementioned issues since 1997. CNNIC (2005) indicates increased confidence in e-Banking, as consumers in China further transact in credit cards and debit 
cards, in lieu of cash, on the on-line Web.

\section{FACTORS OF E-BANKING INTERFACE}

Literature on e-Banking in China is found by the authors of this study to be limited in the United States in defining functionality and interface, which could be considered by bankers in China in influencing if not introducing competitive customer relationship management on the Web. Interface as a principle is introduced by Rayport and Jaworski (2003) for e-Commerce sites. Factors of interface consist of context, content, communication, connection, community, customization and commerce and are helpful in evaluating non-banking and banking sites on the Web. The factors for evaluating the Chinese e-Banking sites of this study are defined below:

- Context - degree of financial content design and navigation on the sites;

- Content - degree and depth of current and helpful financial information on the sites;

- Communication - degree of interactive customer and institution dialogue on the sites;

- Connection - degree of connection to affiliated financial or non-financial sites on the Web;

- Community - degree of interactive customer-to-customer interaction on the sites;

- Customization - degree of customization or personalization of financial or non-financial products and services on the sites; and

- $\quad$ Commerce - extent and security of commercial financial transactions on the sites (Rayport \& Jaworski, 2003).

The factors in the study of Chinese sites are equivalent to factors in studies of United States sites.

\section{FOCUS OF STUDY}

The focus of this study is to evaluate Chinese e-Banking sites on the Web, based on the aforementioned context, content, communication, connection, community, customization and commerce factors of the interface and the functionality of the sites. Intent of the study is to introduce insight that may benefit banking managers, researchers and strategists in China, in competing in not only the domestic Chinese market, but in the increasingly important global market. Study furnishes competitive implications of innovation investment.

\section{RESEARCH METHODOLOGY}

The research methodology of the study consists of an evaluation of a sample of 14 leading banks in China, including city commercial, private and state banks, which began in a graduate Information Systems Research Project Seminar, in the School of Computer Science and Information Systems, of Pace University, in New York City, in fall 2005. Choice of banks in the sample is based on an earlier evaluation of the banks as leader institutions in assets, or on establishment in the financial industry, by Chinese mainland media. The sample of study includes Agricultural Bank of China, Bank of Beijing, Bank of China, Bank of Communications, China Construction Bank, China Merchants Bank, China Everbright Bank, China Minsheng Banking Corporation, CITIC Industrial Bank, Guangdong Development Bank, Huaxia Bank, Industrial Bank Company, Industrial and Commercial Bank of China, and Shanghai Pudong Development Bank. Most of the banks (10) are asset leaders in the industry, as indicated in Table 1, and the others in the study (4) are established in the industry and are frequently cited by the Chinese media (Data Monitor, 2003, Varma, et. al., 2003 \& Chen and Thomas, 1999).

In stage 1 of the study, an exploratory pilot survey had been conducted of a concentrated focus group of 16 adult citizen consumers in China, in close collaboration with one of the Chinese fluent authors of the study, on the effectiveness of e-Banking functionality and interface of the 14 banks. The consumers are aged $24-36$ years, daily and diligent consumers on the Web, and current or former customers of most of the banks. They are graduates of mostly the leading higher education institutions in China, indicated in Table 2, fluent in the Chinese language of the sites, and higher income middle class subjects. These consumer subjects are 55\% male and $45 \%$ female. They reside in the critical growth and infrastructure sections of technology on the east coast of China: Beijing, Guangzhou, and Shanghai (CNNIC, 2005 \& Wong et. al., 2004), indicated in Table 3.

Table 1: Banks in China in Chinese e-Banking Study 
(Dollars in Millions)

\begin{tabular}{|c|c|c|}
\hline Rank & Bank & Assets \\
\hline 1 & Industrial and Commercial Bank of China & 521,085 \\
\hline 2 & Bank of China & 405,664 \\
\hline 3 & China Construction Bank & 333,662 \\
\hline 4 & Agricultural Bank of China & 262,281 \\
\hline 5 & Bank of Communications & 85,469 \\
\hline 6 & CITIC Industrial Bank & 36,215 \\
\hline 7 & China Everbright Bank & 32,028 \\
\hline 8 & China Merchants Bank & 31,162 \\
\hline 9 & Guangdong Development Bank & 23,073 \\
\hline 10 & Shanghai Pudong Development Bank & 20,960 \\
\hline
\end{tabular}

Source: Varma, et. al., 2003

Table 2: Education of Chinese Consumer Subjects in e-Banking Survey

\begin{tabular}{|c|c|c|}
\hline Education & Percentage & University \\
\hline Bachelor & 57.14 & $\begin{array}{l}\text { Beijing International Studies University } \\
\text { Beijing Union University } \\
\text { Peking University } \\
\text { Tianjing University } \\
\text { Tsinghua University } \\
\text { University of International Business and Economics }\end{array}$ \\
\hline Master & 38.10 & $\begin{array}{l}\text { City University of New York } \\
\text { Pace University } \\
\text { University of Auckland } \\
\text { University of Edinburgh } \\
\text { University of Hong Kong } \\
\text { University of Virginia } \\
\text { University of Sydney }\end{array}$ \\
\hline Ph.D. & 4.76 & University of South Africa \\
\hline
\end{tabular}

The survey of the subjects in stage 1 had been conducted by an instrument constructed in English, which had been evaluated by one of the authors who is the instructor of the Research Seminar and subsequently interpreted in Chinese by the Chinese fluent author of the study. The instrument in Chinese had been furnished to the subjects on www.SurveyMonkey.com and included login and password security. This instrument had consisted of 21 items, to be evaluated for perceived effectiveness in functionality and interface, of the related 7 factors of context, content, communication, connection, community, customization, and commerce, on each of the 14 Chinese e-Banking sites, by each of the 16 subjects. Factors had been defined on the instrument with examples by the authors and had been evaluated by the subjects on a 5 -point Likert scale of $5=$ very high, $4=$ high, $3=$ intermediate, $2=$ low, and $1=$ very low functionality and interface. Further interaction of the subjects and the authors on the survey had been enabled in e-Mail and Instant Messenger Services tools of the World Wide Web. Results of the survey had been summarized through the www.SurveyMonkey.com system.

Instrument of survey is available upon request of the authors.

In stage 2 an exploratory case study had been conducted by the authors on China Merchants Bank, one of the institutions in the survey, based on an in-depth Chinese and Asian practitioner literature survey and an evaluation study of the site, in order to attempt to confirm the results in stage 1. In stage 3 further in-depth studies of other consumer subjects and of a number of the banks in the survey, that will include banker manager subjects, will be initiated in mid-2006 by the authors.

Table 3: Residence of Chinese Consumer Subjects in e-Banking Survey 


\begin{tabular}{|c|c|}
\hline East Coast Section & Percentage \\
\hline North (Beijing) & 42.85 \\
\hline Middle (Shanghai) & 33.33 \\
\hline South (Guangzhou) & 23.82 \\
\hline
\end{tabular}

\section{ANALYSIS OF E-BANKING SURVEY}

The analysis of the pilot results of the survey of Chinese consumer subjects is disclosing that that most of the e-Banking sites in the sample have high commerce (means $=4.12$ ), intermediate context (3.86), content (3.85), customization (3.34) and communication (3.19), and low connection (2.95) and community (2.66), in functionality and interface, as summarized in Table 5.

Table 4: Summary Analysis of Chinese e-Banking Survey

\begin{tabular}{|l|c|c|c|c|c|c|}
\hline & $\begin{array}{c}\text { Very Low } \\
\text { Frequency* } \\
\text { Score 1 }\end{array}$ & $\begin{array}{c}\text { Low } \\
\text { Frequency* } \\
\text { Score 2 }\end{array}$ & $\begin{array}{c}\text { Intermediate } \\
\text { Frequency* } \\
\text { Score 3 }\end{array}$ & $\begin{array}{c}\text { High } \\
\text { Frequency* } \\
\text { Score 4 }\end{array}$ & $\begin{array}{c}\text { Very High } \\
\text { Frequency* } \\
\text { Score 5 }\end{array}$ & $\begin{array}{c}\text { Average } \\
\text { Score }\end{array}$ \\
\hline Context & & & & & & \\
\hline Content & 53 & 134 & 325 & 660 & 226 & 3.86 \\
\hline Communication & 60 & 210 & 256 & 476 & 218 & 3.85 \\
\hline Connection & 177 & 166 & 196 & 165 & 70 & 3.19 \\
\hline Community & 47 & 81 & 237 & 210 & 81 & 2.95 \\
\hline Customization & 33 & 11 & 32 & 39 & 19 & 2.66 \\
\hline Commerce & 3 & 18 & 65 & 77 & 38 & 3.34 \\
\hline
\end{tabular}

$* n=16$ consumer subjects $\times 14$ banks $\times 7$ factors $(21$ items $)$ [summarized]

Of note in Table 4 is the higher very high and high frequency scores, in contrast to the lower low and very low frequency scores, on the factors of functionality and interface. Chinese e-Banking is clearly functioning on the sites and is furnishing an apparent basic foundation for relationship management on the Web.

\section{ANALYSIS OF E-BANKING CASE STUDY}

The analysis of China Merchants Bank (www.cmbchina.com) by the authors is disclosing that the bank has equivalent high commerce (4.00 [4.12 in consumer survey]), higher very high to high content (5.00 [3.85]), context (4.00 [3.86]), connection (4.00 [2.95]) community (4.00 [2.66] and communication (4.00 [3.19]), but lower intermediate customization (2.00 [3.34]), in functionality and interface on the site, in contrast to the summarized survey of the consumer subjects. Case study in general is confirming the positive results of the survey. China Merchants Bank excels in its All in One Net commerce and in helpful consumer financial information and navigation on its Web site. Unanticipated is the further positive results in connection and Web blog café community on the site. Consumers may link to not only financial market news sites, but also to family related, real estate and shopping mall sites, and may share in All in One Net Forums, Bond Forums, Credit Card Clubs, Exchange Salons, and Wealth Forums. Estimated consumers in the clubs and forums approximate 215,000 members. Though customization of customer VIP accounts on the Web is low in the case study, the aggregate impact of the results of the other factors is disclosing continued if not improved functionality and interface on the China Merchants Bank site.

Instrument of analysis of China Merchants Bank is available upon request of the authors.

\section{IMPLICATIONS OF STUDY}


The results of the study are indicating that Chinese domestic banks have competent, established, and fully functioning e-Banking on the Web, impacted by accession of China into the World Trade Organization and by intelligent investment by the banking industry ( $\mathrm{Lu}$, et. al., 2004). The banks in the study enable an apparent comprehensive introduction to financial products and services to high income Chinese consumers. They furnish functionality that facilitates not only navigation, but banker interaction and community consumer dialogue on the sites. Information on partnered services on other sites is a feature noticeable on the integrated banking sites. The results of the study are indicating investment in $21^{\text {st }}$ century portal designs that extend the integration of resource services to the basic products of the banks (Bauer, et. al., 2004).

Functionality and information on the e-Banking sites are indicated to be focused on high income consumers in the growth sections of China. Though the information is comprehensive for consumers already educated in the fundamentals of finance and of the financial products, products may not be defined enough for low income consumers, who might desire basic commerce services on the sites. Investment in improved instructional technology on the sites may benefit low income and middle income consumers, if the banks decide such consumers on the Web to be fruitful customers.

Functionality of customization of services to high income Chinese customers on the sites is indicated in the study to be limited, though perceived to be tailored to such customers. Marketing of services personalized to customers, based on diverse information sources, as in the United States, is not noticeable on the sites. One-stop shopping of non-financial and financial services on the sites, through further investment in connection and customization methodologies and technologies, may be a feature for consideration by the banks, in order to increase potential for increased customer relationship.

Final implication of the study is the indication from the results that e-Banking in China is enabling a foundation for customer relationship management. Factors of context, content, communication, connection, community, customization, and commerce are evaluated generally high to intermediate in functionality facilitating interface with Chinese e-Banking consumers. Such a foundation can furnish an edge to Chinese bankers in the future, as international institutions compete for Chinese consumers in the global market.

\section{LIMITATIONS AND OPPORTUNITIES IN RESEARCH}

The small sample of consumers in the study is a clear constraint of the survey. Though the collaboration of the subjects and the authors on the Web was effective in furnishing information on the sites, follow-up by the authors physically in China will enable an in-depth study of a larger sample, subject to governmental approval. The constraining schedule of 14 weeks of the Research Project Seminar in 2005 is a further limitation of the study. Opportunities in research include an in-depth survey of a sample of banker managers of the institutions of this study. Pace University is currently partnering with research organizations and schools in China, which will facilitate a future study of e-Banking in China, potentially hosted by the university.

\section{CONCLUSION}

This review of e-Banking in China is disclosing competitive design of the banks in high to intermediate functionality and interface on a bulk of context, content, communication, connection, community, customization and commerce factors that benefit consumers. The Study contributes important insight that can benefit business directors and technology managers in banks in China who intend to improve e-Banking strategy in the international market. This study is thus timely.

\section{REFERENCES}


1. Ashling, J. (2005) Recent Developments in China, Information Today, 22(4), 1-3.

2. Asia Pulse (2001) China's Internet Banking Transactions Total US\$24 Billion, Asia Pulse News, September $28,0327$.

3. Barbesino, P., Camerani, R., \& Gaudino, A. (2005) Digital Finance in Europe: Competitive Dynamics and On-Line Behavior, Journal of Financial Services Marketing, 9(4), 329-343.

4. Bauer, H., Hammerschmidt, M., \& Falk, T. (2004) Measuring the Quality of e-Banking Portals, International Journal of Bank Marketing, 23(2/3), 153-175.

5. Chen, J. \& Thomas, S.C. (1999) Banking on China, China Business Review, November.

6. China Internet Network Information Center [CNNIC] (2005) $16^{\text {th }}$ Statistical Reports on the Internet Development in China, available at www.cnnic.net.cn/download/2005/2005072601.pdf.

7. Data Monitor (2004) Banks in China: Industry Profile, November, available at www.datamonitor.com.

8. Laforet, S. \& Li, X. (2005) Consumers' Attitudes towards On-Line and Mobile Banking in China, International Journal of Bank Marketing, 23(5), 362-380.

9. Lu, M.T., Liu, C.H., Jin, J., \& Huang, L. (2005) Internet Banking: Strategic Responses to the Accession of WTO by Chinese Bank, Industrial Management \& Data Systems, 105(4), 429-442.

10. Orr, B. (2004) e-Banking Job One: Give Customers a Good Ride, American Bankers Association Banking Journal, 96(5), 56-57.

11. Pikkarainen, T., Pikkarainen, K., Karjaluoto, H., \& Pahnila, S. (2004) Consumer Acceptance of On-Line Banking: an Extension of the Technology Acceptance Mode, Internet Research, 14(3), 224-235.

12. Pyun, C. S., Scruggs, L., \& Nam, K. (2002) Internet Banking in the US, Japan and Europe, Multinational Business Review, Fall, 73-81.

13. Rayport, J. \& Jaworski, B. (2003) Introduction to e-Commerce. (McGraw-Hill: New York).

14. Sarel, D. \& Marmorstein, H. (2003) Marketing On-Line Banking Services: The Voice of the Customer, Journal of Financial Services Marketing, 8(2), 106-118.

15. Siaw, I. \& Yu, A. (2004) Analysis of the Impact of the Internet on Competition in the Banking Industry, Using Porter's Five Forces Model, International Journal of Management, 21(4), 514-523.

16. Varma, A., Israel, N. S., Odaka, Y. M., \& Rüeck, G..(2003) Foreign Banks in China: Critical Success Factors and Lessons Learnt, MBA Dissertation, Nanyang Technological University, available at http://www.ntu.edu.sg/nbs/mba/bsm/Shanghai\%20and\%20Suzhou\%20PDF/Group\%209.pdf

17. Wong, X., Yen, D.. \& Fang, X. (2004) e-Commerce Development in China and Its Implications for Business, Asia Pacific Journal of Marketing and Logistics,16(3), 68-83. 